\title{
Perceptions of Quality School Facilities - Implications for the School Administrator
}

\author{
Mary Keller Boudreaux, Ed.D ${ }^{1}$, Rosalind Martin, Ed.D (deceased) ${ }^{1,2} \&$ Larry McNeal, Ph.D (deceased) ${ }^{1}$ \\ ${ }^{1}$ College of Education, University of Memphis, Memphis, Tennessee, USA \\ ${ }^{2}$ Shelby County Schools, Memphis, Tennessee, USA \\ Correspondence: Mary Keller Boudreaux, Ed.D, College of Education, Univesity of Memphis, Memphis, TN., 38152, \\ USA. Tel: 1-901-678-5924.
}

Received: October 13, 2015

Accepted: October 26, 2015

Online Published: July 21, 2016

doi:10.5430/irhe.v1n2p164

URL: http://dx.doi.org/10.5430/irhe.v1n2p164

\begin{abstract}
The elements that comprise a school's climate are extensive and complex. There is a preponderance of evidence in the literature that suggest a strong relationship between school climate and academic achievement at the school level. However, there is insufficient research on the elements of school facilities and its relationship to student academic achievement. This paper presents the survey results of 3453 elementary and middle school teacher respondents to the 2010 Administration of the Measures of Effective Teaching Working Conditions Survey on their perceptions of school facilities and its relationship to reading and math on the 2010 Tennessee Comprehensive Achievement Program (TCAP) assessment. Results indicated there were no significant differences between elementary and middle school teachers' perceptions about quality school facilities. However, there was a difference in teachers' perceptions of those who worked in schools with proficient reading and math scores on standardized test.
\end{abstract}

Keywords: school climate, school facilities, academic achievement, school leadership

\section{Introduction}

Specific research on school climate in high-risk urban environments indicates that a positive, supportive, and culturally conscious school climate can significantly shape the degree of academic success experienced by urban students (Haynes \& Comer, 1993). One of the mechanisms that may explain how school climate affects individual outcomes is school connectedness (Loukas, 2007). School connectedness is defined as student perceptions of belonging and closeness with others at the school. Some researchers consider school connectedness as a component of school climate that is richly impacted by relationships within the school building (Loukas, 2007). The Healthy Schools Network (2013) supports this statement positing:

"We do not do enough to protect our children: unhealthy schools impose a grave injustice. States compel children to attend school; in fact, $98 \%$ of all school-age children attend schools-irrespective of conditions. Yet the environmental conditions of decayed facilities or facilities close to hazards can damage children's health and ability to learn. At the same time, it is well documented that healthy school facilities can help children learn, grow, and stay healthy" (p. 5).

In addition to the many challenges plaguing urban, low-income, high-risk schools and students, several factors can have a positive impact on urban education and level the field for improving student achievement. One of the most critical is quality school facilities. According to Learning First Alliance (LFA) (as cited in Emerick, Hirsch, \& Barry, 2005), basic working conditions in high-poverty, low-performing schools are often far worse than any professional should be asked to tolerate, and it is hardly surprising that such conditions are a major cause of high teacher turnover in many urban schools. The report predicts that even excellent teachers struggle when faced with poor facilities (Emerick, Hirsch, \& Barry, 2005). Such poor facilities in schools have both indirect and direct negative impact on the facilitation of teaching and learning, particularly in less progressive neighborhoods and schools. The crisis in urban schools and the achievement gap between upper-income and lower-income students is a monumental problem facing school districts all across the country. Too few students are graduating from public schools prepared for college or a career (Boudreaux, McNeal \& Martin, 2015). The nation's commitment to provide a free and public education in order to prepare children to participate in social equality is not living up to the promise (Boudreaux, 
McNeal \& Martin, 2015).

The researchers in this study believe that the element of quality school facilities is critical to student performance in urban, low-income, high-risk elementary and middle schools and therefore proposes this quantitative study on the relationship between the variable of school facilities and student achievement as it is perceived by teachers in these schools.

\subsection{Theoretical Framework}

The theoretical foundation for this study draws from psychological research on motivation, more specifically, Bernard Weiner's (1974) Attribution Theory Framework. The theory of motivation explains the behaviors and attitudes of employees, and aids this researcher in developing the foundation for this study (Rowley, 1996). This is one of the most influential theories of academic motivation. The main principle of the attribution theory as it applies to motivation is that a person's own perceptions or attributions for success or failure determine the amount of effort the person expends on an activity in the future. The researcher examines the data to see if this theory's assumption that people will interpret their environment in such a way to maintain a positive self-image is true.

\subsection{Literature Review}

One particular aspect of school climate that impacts job satisfaction and student achievement is the school building itself. Routinely found in many urban school settings, conditions of the facilities may include, peeling paint, broken windows, non-compliance with American Disability Act requirements, poor lighting, and inadequate instructional space (Marx, 2006). Often such circumstances can influence how employees feel about their working conditions and how students feel about their learning environment. Two important components that influence teachers' perceptions about their working environment are adequate space and physical environment of the classroom.

\subsubsection{Adequate Space to Work Productively}

While there is a consistent correlation between the quality of a building and children's academic performance, research shows an even stronger link between teacher work space and teacher motivation, effective teaching takes place when teachers have enough space for children to learn (Atkinson, 2000). According to Gordon (2000), classroom-based workspaces in the average middle school should be designed for use by an individual teacher, as a shared space for several teachers, or as a temporary place for teachers who carry their materials with them. In general, Gordon (2000) indicates that a classroom-based teacher workspace should include wiring for an intercom/telephone and a computer. Gordon (2000) advocates that adequate storage should be provided in the forms of file cabinets, closets, and cupboards. Because middle school teachers engage in a wide variety of activities that demand some level of privacy, storage spaces for teachers and students should be designated and clearly marked.

In 2009, a study conducted by the Children's Investment Fund reported that teachers working in good spaces feel better about their work and are more engaged and positive with children. The physical environment on children's social, emotional, and cognitive development is essential. This study supports Holt's (1995) research stating that the attitudes, behaviors, and relationships among students and staff were more conducive to learning in schools and teachers working in good spaces feel better about their work which created more positive engagement with students.

On the contrary, often observed, middle schools in some urban districts are lacking the proper resources needed to properly prepare students, not only for high school academics, but facilities are ill-equipped to prepare students for athletic programs. Often athletic programs in many of the schools are non-existent because of the lack of facilities or due to space to support such a program. In other cases, the classes are overcrowded and space is limited for small group instruction. Many of the middle schools still have cafetoriums instead of auditoriums. Some school districts still have middle grades in elementary or high school settings.

\subsubsection{Physical Environment}

Stone (2009) defines the physical environment of a classroom as the structural elements of a classroom such as desk placement and wall color choice. The literature has identified studies where the facility had a negative impact on students and their academic growth. For example, Kozol (1991) studied urban schools and reported that Mary McCloud Bethune Elementary School in East St. Louis, Illinois had traces of lead in the water and the paint peelings tested positive with poison. Students were consistently treated at local hospitals for lead poisoning. Kozol (1991) stressed the cleaning crew was short-staffed and that one person was assigned to clean the entire school. Limited budgets and bureaucracy caused this school to have issues with receiving proper cleaning on a daily basis and adequate cleaning supplies to maintain a clean and well maintained environment.

According to a school facilities researcher, Engelbrecht (2009), color is an important structural element of the facility 
and it can have benefits for the classroom. However, Engelbrecht (2009) contends that the mental stimulation passively received by the color helps the student and teacher stay focused and yield positive feeling and attitudes. Based on his study, younger children are stimulated by bright colors while older students respond better to blues and greens. It is believed that the understanding of color differences helps teachers make informed decisions about how to accent the classroom for effective student learning while creating a suitable work environment for themselves. Englebretch (2009) also states that lighting, music, visually appealing walls, separate areas for various activities, opportunity for movement and flexibility in the room all work together to create a classroom most conducive to learning. Combine these elements with classroom teachers who are excited about what they're teaching, and you have a learning environment that nurtures the whole child - socially, emotionally and academically.

\subsubsection{School Facilities and Student Achievement}

The literature has identified instances that validate a strong correlation between the condition of school facilities and student achievement. There are case studies that examine the relationship between building conditions and student achievement (see Berner, 1993; Buckley, Schneider, \& Shang, 2004; McGuffey, 1982).

Lumpkin (2013) measured the passing rate of the Florida Comprehensive Assessment Test (FCAT) of fourth, eighth, ninth, and tenth grade students after transitioning to a new school. Results of the study indicated that students moving from an old school building into a new 2000 State Uniform Building Code for Public Educational Facilities Construction (UBC) compliant facility increased their mean schools on both mathematics and reading subtests of the FCAT. The evidence provided in this causal-comparative study suggests that the school environment has a direct relationship to student academic achievement.

Bryk, Sebring, Allensworth, Luppescu, and Easton (2010) provide evidence of substantial improvement in 100 public elementary Chicago schools in reading and math over a seven-year period. The outcome of such longitudinal study provides implications regarding educational reform orchestrated across several domains: school leadership, professional capacity, parent-community ties, student-centered learning climate, and instructional guidance. The key findings included:

- Improvements in test scores depended on adult cooperative work focused on instruction. Schools where teachers report their colleagues are continually learning, committed and loyal and have can-do attitudes were three times less likely to stagnate in math than schools weak on this measure.

- Schools with strong parental involvement were 10 times more likely to improve substantially in math than schools with weak parental involvement.

- School improvement is highly unlikely to occur without a strong principal. Schools with strong leadership were seven times more likely to improve substantially in math than schools with weak leadership.

- Organizational structures are vitally interconnected. Weakness in one support can amplify the negative effects of another weakness, while strength in one can amplify the positive effects of another. For instance, weak safety and order, together with poor instruction, virtually guaranteed poor attendance. (p. 2).

Sheets' (2009) dissertation examined the relationship between the conditions of school facilities and educational outcomes in 72 rural high schools in Texas. The study found the condition of school facilities had a measureable effect on student achievement and teacher turnover. Moreover, schools with inadequate facilities, portable classrooms or deferred maintenance had lower student achievement on standardized tests.

Uline and Tschannen-Moran (2008) measured school climate, particularly school facilities, within 80 Virginia middle schools. The findings indicated that school climate played a mediating role on the effects of school facilities and student achievement. The study concluded that when students are learning within less than desireable facilities, student achievement is clearly less of focus. As well, teachers show very little motivation towards teaching and supporting student learning within their classrooms.

In another example, Cash (1993) found that comfort factors in the school building design appeared to have more of an effect on student achievement than structural factors. The comfort factors included schools that were located in less noisy locations, were air conditioned, had less graffiti and classroom furniture and student lockers in good repair. Schneider (2002) found the quality of school buildings is also related to student behavior, absenteeism, violence, smoking, vandalism, and suspensions. Temperature within the school building, heating and air quality are rated by Earthman (2004) as the more important individual elements affecting student achievement. Thus, building conditions are important factors in a school environment (Earthman, 2004; Schneider, 2002).

There are a multitude of factors that contributes to the conditions of schools. In the Buckley, Schneider, and Shang 
(2004) study, two-thirds of the teachers reported poor indoor air quality in their school. Poor indoor air quality within a building is also known as "sick building syndrome." Buildings that are labeled as "sick" contribute to the decrease in student achievement and an increase teacher attrition. Moreover, since school buildings in the United States are, on average, over forty years old, just the time when rapid deterioration often begins, the school community should expect problems with school facilities and illness to worsen (Berner, 1993; Buckley, Schneider, \& Shang, 2004). Teachers placed in facilities that require extensive repair, often facilitate a hopeless state for improved conditions and ultimately impacts their ability to improve instruction in such working conditions.

In conclusion, effective school leaders ensure that schools are organized in a manner where the climate ensures continuous growth for the teacher and the students, (Mendels, 2012). In most cases, a healthy school climate goes beyond the basics of safety and order, but to a climate that is supportive and responsive to teachers' perceptions of facilities that emanate developmental responsiveness that are contributing factors to the increase of student achievement.

\subsection{Research Questions}

The researchers submitted two specific questions to be answered by this study. In order to answer the research, this study will use a quantitative methodology that facilitates an analysis of the variables in the study. The quantitative methodology will be a useful research design for explaining variables and the relationship among them (Creswell, 2008). The researchers determined that a non-experimental approach utilizing descriptive and correlational statistics will be the most appropriate for a secondary data analysis study.

The study is guided by the following two research questions:

1. How do urban school teachers perceive facilities at their schools and do these perceptions differ by school type?

2. What relationships are observed between urban teachers' perceptions of facilities and student achievement in reading and math?

\section{Method}

This study presents the results of a secondary data analysis of 3453 teacher responses on one section of the Measures of Effective Teaching/Working Conditions Survey, regarding school facility resources as they impact school climate and ultimately student achievement.

\subsection{Participants}

Schools in this study were elementary and middle schools, all located in a large district in the Southeastern United States which was selected based on the grade configuration. The total enrollment for the large urban district was 102, 798 students in 2009 school year. School sizes varied from 248 to 1007 in the elementary schools, with a mean enrollment of 677. Economically disadvantaged status at the school level was determined by the percentage of students eligible for free or reduced lunch, which ranged from 15\% to $96 \%$. School sizes varied from 248 to 1007 in the elementary schools, with a mean enrollment of 677.

The teacher sample consisted of elementary and middle school teachers. The MET (Measures of Effective Teaching) Working Conditions Survey was administered to 3453 elementary and middle school respondents at 206 district "sites" (Swanlund, 2011). The results are displayed in Table 1 and Table 2.

Table 1. Total years employed as an educator $(n=3453)$

\begin{tabular}{lll}
\hline Group & $\begin{array}{l}\text { Elem } \\
(n=2565)\end{array}$ & $\begin{array}{l}\text { Middle } \\
(n=888)\end{array}$ \\
& $\%$ & $\%$ \\
\hline First Year & 3.0 & 7.0 \\
2 to 3 Years & 6.9 & 12.2 \\
4 to 6 Years & 9.2 & 17.6 \\
7 to 10 Years & 18.6 & 17.7 \\
11 to 20 Years & 33.1 & 25.8 \\
$20+$ Years & 29.0 & 19.5 \\
Not Answered & 0.2 & 0.3 \\
\hline
\end{tabular}


Table 2. Total years employed at present school $(\mathrm{n}=3453)$

\begin{tabular}{lll}
\hline Group & $\begin{array}{l}\text { Elem } \\
(n=2565) \\
\%\end{array}$ & $\begin{array}{l}\text { Middle } \\
(n=888) \\
\%\end{array}$ \\
\hline First Year & 10.4 & 15.1 \\
2 to 3 Years & 16.2 & 26.4 \\
4 to 6 Years & 20.2 & 23.8 \\
7 to 10 Years & 19.9 & 14.3 \\
11 to 20 Years & 19.0 & 11.8 \\
$20+$ Years & 9.0 & 4.1 \\
Not Answered & 5.3 & 4.6 \\
\hline
\end{tabular}

\subsection{Data Collection}

Before the initiation of this study, the researcher obtained secondary data taken from a selected school district in a large urban district in the Southeastern United States during the 2009-2010 school years. The data was utilized by the district and school administration to promote school improvement, provide a foundation for assessing professional development, implementation of research-based strategies for improvement, and policy development guidance. Prior to conducting the research for this study, permission was requested from the Institution Review Board (IRB) to conduct the study. The secondary data was collected from the Tennessee State Department of Education website.

\subsubsection{Measures}

A review of the literature indicates that a wide variety of school climate inventories are in use. Witcher (1993) reviewed several of these instruments and found that those generating information about multiple aspects of the school resulted in the most reliable assessments. The criteria used to select an appropriate instrument included ease of administration, validity and reliability, appropriateness for elementary, middle, and high schools, and an emphasis on teacher working conditions. The survey that fits these selection criteria is the MET (Measures of Effective Teaching) Working Conditions Survey (New Teacher Center, 2009). The MET Working Conditions Survey analyses presented are based on the responses to a survey instrument that was based on the North Carolina Teacher Working Conditions Survey (Hirsch \& Church, 2009), but customized to Tennessee.

\subsection{Research Design}

The researchers used secondary data to analyze teachers' perceptions of student academic achievement related indices of instructional resources and their relationship to student academic achievement. A descriptive analysis was performed on the sample group to obtain a clear understanding of the group. Measures of central tendency and distribution was conducted. The researchers determined means, medians, and percentiles based on the data input. Standard deviations will also be determined during data analysis and reported as well. This quantitative study used correlation analysis to analyze the data. In the correlation analysis, the researchers were able to determine the strength of the relationships between school facilities and student achievement.

\section{Results}

Research question 1 concerns urban elementary and middle school teachers' perceptions' of the overall quality of the facilities at their schools and whether these perceptions differ by school type. With respect to this question, frequencies and percentages were obtained for each of four "facilities-related" items on the MET/Working Conditions Survey for all elementary school teacher respondents (Table 3) and middle school teacher respondents (Table 4). Complementing these two tables of frequencies and percentages are two additional tables in which means and standard deviations have been computed and compared for subgroups of elementary and middle school teachers given the responses of individuals as the unit of analysis (Table 5) and responses aggregated to the school- or faculty-level as the unit of analysis (Table 6). With all of these responses pertinent to the overall quality of the facilities for improving a climate of academic achievement in schools, these four "facilities-related" items read as follows:

1. The school environment is clean and well maintained. 
2. Teachers have adequate space to work productively.

3. The physical environment of the classrooms in this school supports teaching and learning.

4. The reliability and speed internet connections in this school are sufficient to support instructional practices

Table 3. Frequencies and percentages for facilities-related items: Elementary level respondents

\begin{tabular}{|c|c|c|c|c|c|c|c|c|c|c|}
\hline \multirow[t]{2}{*}{ Item } & \multicolumn{2}{|c|}{$\begin{array}{l}\text { Strongly } \\
\text { Disagree }\end{array}$} & \multicolumn{2}{|c|}{ Disagree } & \multicolumn{2}{|c|}{ Agree } & \multicolumn{2}{|c|}{$\begin{array}{l}\text { Strongly } \\
\text { Agree }\end{array}$} & \multicolumn{2}{|c|}{ NA } \\
\hline & $n$ & $\%$ & $N$ & $\%$ & $n$ & $\%$ & $n$ & $\%$ & $n$ & $\%$ \\
\hline $\begin{array}{l}\text { The school environment is } \\
\text { clean and well maintained. }\end{array}$ & 138 & 5.0 & 341 & 12.3 & 1405 & 50.8 & 826 & 29.9 & 55 & 2.0 \\
\hline $\begin{array}{l}\text { Teachers have adequate } \\
\text { space to work } \\
\text { productively. }\end{array}$ & 127 & 4.6 & 359 & 13.0 & 1607 & 58.1 & 639 & 23.1 & 33 & 1.2 \\
\hline $\begin{array}{l}\text { The physical environment } \\
\text { of classrooms in this } \\
\text { school supports teaching } \\
\text { and learning. }\end{array}$ & 97 & 3.5 & 254 & 9.2 & 1615 & 58.4 & 760 & 27.5 & 39 & 1.4 \\
\hline $\begin{array}{l}\text { The reliability and speed } \\
\text { of Internet connections in } \\
\text { this school are sufficient to } \\
\text { support instructional } \\
\text { practices. }\end{array}$ & 344 & 12.4 & 676 & 24.4 & 1295 & 46.8 & 419 & 15.2 & 31 & 1.1 \\
\hline
\end{tabular}

As it regards facilities (Table 3), over $80 \%$ of elementary teachers appear to agree that the facilities are clean and well maintained (83.4\%), that their work space is sufficient $(80.7 \%)$, and that the physical environment is supportive of teaching and learning $(85.9 \%)$. Surprisingly, however, more than one-third of all responding elementary teachers disagreed when asked about "the reliability and sufficiency of internet connections...to support instructional practices" $(36.8 \%)$.

Table 4. Frequencies and percentages for facilities-related items: Middle level respondents

\begin{tabular}{|c|c|c|c|c|c|c|c|c|c|c|}
\hline \multirow[t]{2}{*}{ Item } & \multicolumn{2}{|c|}{$\begin{array}{l}\text { Strongly } \\
\text { Disagree }\end{array}$} & \multicolumn{2}{|c|}{ Disagree } & \multicolumn{2}{|c|}{ Agree } & \multicolumn{2}{|c|}{$\begin{array}{c}\text { Strongly } \\
\text { Agree }\end{array}$} & \multicolumn{2}{|c|}{ NA } \\
\hline & $n$ & $\%$ & $N$ & $\%$ & $N$ & $\%$ & $N$ & $\%$ & $n$ & $\%$ \\
\hline $\begin{array}{l}\text { The school environment is } \\
\text { clean and well maintained. }\end{array}$ & 37 & 4.2 & 91 & 10.2 & 450 & 50.7 & 290 & 32.7 & 20 & 2.3 \\
\hline $\begin{array}{l}\text { Teachers have adequate } \\
\text { space to work productively. }\end{array}$ & 42 & 4.7 & 106 & 11.9 & 503 & 56.6 & 225 & 25.3 & 12 & 1.4 \\
\hline $\begin{array}{l}\text { The physical environment of } \\
\text { classrooms in this school } \\
\text { supports teaching and } \\
\text { learning. }\end{array}$ & 34 & 3.8 & 84 & 9.5 & 528 & 59.5 & 234 & 26.4 & 8 & 0.9 \\
\hline $\begin{array}{l}\text { The reliability and speed of } \\
\text { Internet connections in this } \\
\text { school are sufficient to } \\
\text { support instructional } \\
\text { practices. }\end{array}$ & 96 & 10.8 & 188 & 21.2 & 434 & 48.9 & 164 & 18.5 & 6 & 0.7 \\
\hline
\end{tabular}


As shown in Table 4, the responses of middle school teachers to the facilities-related items were similar to those among elementary school teachers, with some $83.4 \%$ of the former agreeing that facilities are clean and well maintained, some $81.9 \%$ agreeing that their work space is sufficient, and some $85.9 \%$ agreeing that the school's physical environment is supportive of teaching and learning. While somewhat more middle teachers than elementary school teachers felt that "the reliability and speed of Internet connections" were sufficient for instructional purposes, almost one-third of their number perceived this not to be the case (32\%).

Table 5. Means and standard deviations computed from individualized teacher responses for facilities-related and scale by grade level

\begin{tabular}{llllllll}
\hline Item & \multicolumn{3}{c}{ Elementary } & & \multicolumn{3}{c}{ Middle } \\
& $n$ & $M$ & $S D$ & $N$ & $M$ & $S D$ \\
\hline $\begin{array}{l}\text { The school environment is clean and well } \\
\text { maintained. }\end{array}$ & 2514 & 3.06 & 0.80 & 868 & 3.14 & 0.77 \\
$\begin{array}{l}\text { Teachers have adequate space to work } \\
\text { productively. }\end{array}$ & 2536 & 2.99 & 0.74 & 876 & 3.04 & 0.75 \\
$\begin{array}{l}\text { The physical environment of classrooms in this } \\
\text { school supports teaching and learning. }\end{array}$ & 2529 & 3.10 & 0.71 & 880 & 3.09 & 0.71 \\
$\begin{array}{l}\text { The reliability and speed of Internet connections } \\
\text { in this school are sufficient to support } \\
\text { instructional practices. }\end{array}$ & 2540 & 2.64 & 0.89 & 882 & 2.76 & 0.88 \\
\begin{tabular}{l} 
Statistics for Scale \\
\hline
\end{tabular} & 2452 & 2.95 & 0.60 & 852 & 3.01 & 0.61 \\
\hline
\end{tabular}

Table 6. Means and standard deviations computed from school-level teacher responses for facilities-related items and scale by grade level

\begin{tabular}{|c|c|c|c|c|c|c|}
\hline \multirow{3}{*}{ Item } & \multirow{2}{*}{\multicolumn{2}{|c|}{$\frac{\text { Elementary }}{(n=112)}$}} & \multirow{2}{*}{\multicolumn{2}{|c|}{$\begin{array}{l}\underline{\text { Middle }} \\
(n=39)\end{array}$}} & \multirow{3}{*}{$t$} & \multirow{3}{*}{$d$} \\
\hline & & & & & & \\
\hline & $M$ & $S D$ & $M$ & $S D$ & & \\
\hline $\begin{array}{l}\text { The school environment is clean and well } \\
\text { maintained. }\end{array}$ & 3.13 & 0.44 & 3.13 & 0.45 & -0.10 & -0.01 \\
\hline $\begin{array}{l}\text { Teachers have adequate space to work } \\
\text { productively. }\end{array}$ & 3.01 & 0.34 & 3.06 & 0.37 & -0.73 & -0.06 \\
\hline $\begin{array}{l}\text { The physical environment of classrooms in this } \\
\text { school supports teaching and learning. }\end{array}$ & 3.12 & 0.29 & 3.08 & 0.38 & 0.81 & 0.07 \\
\hline $\begin{array}{l}\text { The reliability and speed of Internet connections } \\
\text { in this school are sufficient to support } \\
\text { instructional practices. }\end{array}$ & 2.64 & 0.34 & 2.79 & 0.39 & $-2.24^{*}$ & -0.18 \\
\hline Statistics for Four-Item Scale & 2.98 & 0.29 & 3.01 & 0.33 & 0.69 & 0.06 \\
\hline
\end{tabular}

As with teacher responses to the resources-related items, there was little difference in their responses to the facilities-related items, either at the individual-level (Table 5) or the group-level (Table 6). As suggested above, there 
appears to be some difference in elementary and middle school teachers' perceptions of the functionality of their connections to the internet for instructional purposes $(\mathrm{t}(149)=-2.24, p<.05, d=-0.18)$. This result is understandable as elementary schools tend to have older computers that are primarily used for student practice in acquiring basic skills and for enrichment purposes.

Table 7. Correlations between facilities-related item and scale means and percent proficient in TCAP reading and mathematics 2010 for all schools and by grade level

\begin{tabular}{|c|c|c|c|c|c|c|}
\hline \multirow[t]{2}{*}{ Item } & \multicolumn{2}{|c|}{$\begin{array}{c}\underline{\text { All }} \\
(N=147)\end{array}$} & \multicolumn{2}{|c|}{$\begin{array}{l}\text { Elementary } \\
(n=110)\end{array}$} & \multicolumn{2}{|c|}{$\begin{array}{l}\underline{\text { Middle }} \\
(n=37)\end{array}$} \\
\hline & Read & Math & Read & Math & Read & Math \\
\hline $\begin{array}{l}\text { The school environment is clean and } \\
\text { well maintained. }\end{array}$ & $.17^{*}$ & $.18^{*}$ & 0.19 & $.20 *$ & 0.11 & 0.15 \\
\hline $\begin{array}{l}\text { Teachers have adequate space to work } \\
\text { productively. }\end{array}$ & -0.08 & -0.04 & -0.11 & -0.06 & 0.03 & 0.09 \\
\hline $\begin{array}{l}\text { The physical environment of classrooms } \\
\text { in this school supports teaching and } \\
\text { learning. }\end{array}$ & $.17^{*}$ & $.21 *$ & 0.18 & $.19^{*}$ & 0.14 & 0.18 \\
\hline $\begin{array}{l}\text { The reliability and speed of Internet } \\
\text { connections in this school are sufficient } \\
\text { to support instructional practices. }\end{array}$ & 0.04 & 0.01 & 0.01 & 0.05 & 0.17 & 0.17 \\
\hline Correlations for Scale & 0.09 & 0.11 & 0.08 & 0.12 & 0.13 & 0.18 \\
\hline
\end{tabular}

Research question 2 concerns the extent of the relationship between the mean results from the urban elementary and middle teachers' perceptions of four "facilities-related" items and a scale mean derived from these items and concurrent indices of student achievement at their schools. After aggregating individual teacher perceptions of facilities to the school level, these school-level means were merged with publically-available "report card" data concerning each school's percentage of students proficient and advanced in Reading on the 2010 TCAP and each school's percentage of students proficient and advanced in Mathematics on the 2010 TCAP. As shown in table 7 , there were no statistically significant relationships observed at the middle school level between teacher responses to any of the facilities-related items and TCAP achievement results in either Reading or Mathematics. However, with respect to both "all schools" and the 110 elementary schools, statistically significant relationships were observed for two of the four facilities-related items. For the entire group of 147 schools, TCAP outcomes for both subject matters were linked to teacher perceptions concerning the cleanliness of school environment ( $r=0.17$ in Reading, $r=0.18$ in Mathematics) and to the physical environment of the classrooms ( $r=0.17$ in Reading, $r=0.21$ in Mathematics) but only for TCAP mathematics the 110 elementary schools $(r=.20$ for the former item, $r=0.19$ for the latter item) when analyzed independently. No relationships between student outcomes and teacher perceptions were observed for the remaining two facilities-related items or for the four-item scale taken as a whole.

\section{Discussion and Conclusion}

The researchers sought to identify aspects found in high achieving schools' climates that could attribute to their success. The literature identified multiple contributors; however, for this study the researchers analyzed the responses from classroom teachers by the use of a secondary data set related to the teachers' perception about the overall quality of the facilities in which they work.

According to the data results, both groups of teachers believe that the school facilities are clean and well maintained, and that their work space is sufficient and supportive for the teaching and learning process. Also both groups felt the reliability and sufficiency of internet connections that support instructional practices should be enhanced. This feeling was more prevalent among elementary school teachers and is reasonable since elementary schools tend to 
have older computers that are primarily used for student practice and enrichment activities.

The last set of data reviewed was the relationship between the mean results from elementary and middle school teachers' perceptions about the related items concerning facilities and that of schools whose achievement results were proficient in reading and math on the 2010 Tennessee Comprehensive Achievement Program (TCAP) assessment. All teachers from schools with proficient reading and math results deem the facilities clean and conducive for teaching and learning, but more specifically, elementary math teachers viewed this item as one that supports teaching and learning more succinctly.

Although, the literature indicated that school climate does impact student achievement, it also identified that a learning environment must have certain attributes in order to facilitate effective teaching and learning. Based on the surveyed items related to facility, the responding teachers did not see these aspects as a major concern that hindered teaching and learning, or were they considered as dissatisfiers for job performance.

In light of the continuous search for school reform models that effectively consider all aspects of the school organizational structures, the researcher addressed considerations from the teachers' perceptions about their working environment and set out to determine if there was a relationship to student achievement. The aspects, of the school environment found in the literature and substantiated by the surveyed respondents that motivate teachers to perform at high academic standards is the quality of the facilities. The findings are in concert with similar studies on facilities and academic achievement, i.e., Uline and Tschannen-Moran (2007) demonstrating "that school climate mediated the perceptions of the quality of school facilities and student achievement" (p. 66).

Urban schools continue to search for teachers who can make a difference in educating the students they serve. It is the role of school leaders to provide a work environment that facilitates student success. School leaders cannot control the socioeconomic status of the students they serve, but they can control the conditions in which students are served, i.e., facilities (Sheets, 2009). Lyons (2001) indicates that school facilities “... may have a stronger effect on student performance than the combined influences of family background, socioeconomic status, school attendance, and behavior" (p. 7). If so, the principal as instructional leader in the school must provide quality facilities for the students he or she serves and equitable working conditions for teachers who impact student learning on a daily basis. Based on the information found in this study, elementary and middle school leaders in the Southeastern region of the United States should consider the following Mid-Continent Research for Education and Learning (2005) recommendations concerning the elements of the school climate as it relates to the quality of the facilities in order to motivate teachers to achieve high levels of academic success for students. School leaders should: utilize incentives and disincentives to motivate teachers, communicate to faculty and staff the research basis of effective change in the school, be a risk taker when supporting new teacher ideas, and generate quick goals or wins and continue to implement school improvement plans for change to occur within his or her organization (p. 10).

\section{References}

Atkinson, E. S. (2000). An investigation into the relationship between teacher motivation and pupil motivation. Educational Psychology, 20(1), 45-57. http://dx.doi.org/10.1080/014434100110371

Black, S. (2003). Stressed out in the classroom. American School Board Journal, 190(10), 36-38.

Berner, M. (1993). Building conditions, parental involvement, and student achievement in the District of Columbia Public School System. Urban Education, 28(1), 6-29. http://dx.doi.org/10.1177/0042085993028001002

Boudreaux, M. K., McNeal, L., \& Martin, R. (2015). Elementary and middle school teachers' perceptions of instructional time: Implications for school administrators. International Journal of Multidisciplinary Academic Research, 3(3), 39-49.

Bryk, A. S., Sebring, P. B., Allensworth, E., Luppescu, S., \& Easton, J. Q. (2010). New book by consortiumresearchers identifies proven formula for successful school reform in chicago - Press release. The Universityof Chicago: The University of Chicago Consortium on Chicago School Research. Retrieved from https://ccsr.uchicago.edu/publications/organizing-schools-improvement-lessonschicago

Buckley, J., Schneider, M. \& Shang, Y. (2004). The effects of school facility quality on teacher retention in urban school districts. Washington, DC: National Clearinghouse forEducational Facilities.

Creswell, J. (2008). Educational research: Planning, conducting, and evaluating quantitative and qualitative research (3rd ed.). New Jersey: Prentice Hall.

Earthman, G.I. (2004). Prioritization of 31 criteria for school building adequacy. Baltimore, MD: American Civil Liberties Union Foundation of Maryland. 
Emerick, S., Hirsch, E., \& Berry, B. (2005). NCLB and teachers: Does highly qualified mean high-quality? ASCD Infobrief, 39, 1-8.

Engelbrecht, K. (2003). The impact of color on learning. Chicago, IL: Perkins \& Will.

General Accounting Office. (1995). School facilities: America's schools not designed or equipped for $21^{\text {st }}$ century. Washington, DC: Author. (ED383056).

Gordon, D. (2010). Teacher spaces. Washington, DC: National Clearinghouse for Educational Facilities. Retrieved from http://www.ncef.org/pubs/teacherspace.pdf

Haynes, N. M., \& Comer, J. P. (1993). What is school climate? Urban Education, 28(2), 166-199. http://dx.doi.org/10.1177/0042085993028002004

Healthy Schools Network. (2013). Healthy and high performance schools: ESEA-No child left behind act of 2001. Retrieved from http://www.healthyschools.org/HHPS_Act_2002.pdf

Holt, J. (1995). How Children Learn. New York: Addison Wesley Publishing Company.

Kozol, J. (1991). Savage Inequalities: Children in America's Schools. New York: Crown Publishers.

Loukas, A. (2007). What is School Climate? Leadership Compass, 5(1), 1-3.

Lumpkin, R. B. L. B. (2013). School facility condition and academic outcomes. International Journal of Facility Management, 4(3). Retrieved from http://www.ijfm.net/index.php/ijfm/article/viewFile/91/88

Lyons, J. B. (2001). Do school facilities really impact a child's education? Council of Educational Facility Planners International, Scottsdale, Arizona, 1-7.

Marx, G. (2006). Sixteen trends: Their profound impact on the future implications for students, education, communities, and the whole of society. Alexandria, VA: Educational Research Services.

McGuffey, C. (1982). Facilities: Improving educational standards and productivity. Berkley, CA: McCutchan Publishing Corporation.

Mendels, P. (2012). The effective principal. Retrieved from http://www.wallacefoundation.org/knowledge-center/school-leadership/effectiveprincipal-leadership/Pages/ThEffecti ve-Principal.aspx

Mid-Continent Research for Education and Learning. (2005). Final report: High-needs schools — what does it take to beat the odds? Retrieved from http://www.mcrel.org/ /media/Files/McREL/Homepage/Products/01_99/prod57_BeatTheOdds.ashx

New Teacher Center. (2009). Teaching and learning conditions survey. Retrieved April 12, 2012, from http://newteachercenter.org/node/1359

Rowley, J. (1996). Motivation and academic staff in higher education. Quality Assurance in Higher Education, 4, 11-16. http://dx.doi.org/10.1108/09684889610125814

Schneider, M. (2002). School facilities and academic outcomes. Washington DC: National Clearinghouse for Educational Facilities. Retrieved from http://files.eric.ed.gov/fulltext/ED470979.pdf

Shang, Y. (2004). LAUSD School Facilities and Academic Performance. Washington, DC: National Clearinghouse for Educational Facilities. Retrieved from http://www.edfacilities.org/pubs/LAUSD\%20Report.pdf

Sheets, M. E. (2009). The relationship between the condition of school facilities and certain educational outcomes, particularly in rural public high schools in texas. (Unpublished doctoral dissertation). Texas Tech University, Lubbock, TX.

Stone N. J. (2001). Designing effective study environments. Journal of Environmental Psychology, 21, 179-190. http://dx.doi.org/10.1006/jevp.2000.0193

Swanlund, J. (2011). Tell Tennessee teaching working conditions survey. Retrieved January 20, 2012, from http:www.Tennessee.gov/education

Uline, C., \& Tschannen-Moran, M. (2008). The walls speak: the interplay of quality facilities, school climate, and student achievement. Journal of Educational Administration, 46(1), 55-73. http://dx.doi.org/10.1108/09578230810849817

Weiner, B. (1974). Achievement motivation and attribution theory. Morristown, N.J.: General Learning Press.

Witcher, A. E. (1993). Assessing school climate: An important step for enhancing school quality. NASSP Bulletin, 77(554), 1-5. 